\title{
Diversity of the genus Tectaria Cav. (Polypodiaceae) in Eastern Himalaya and North East India
}

\author{
Sachin M. Patil ${ }^{1,2}$, Vinay M. Raole ${ }^{1}$, Vineet K. Rawat ${ }^{3}$ and Kishore S. Rajput ${ }^{1,}$ \\ ${ }^{1}$ Department of Botany, The Maharaja Sayajirao University of Baroda, Vadodara-390 002, India \\ ${ }^{2}$ Department of Botany, Modern College of Arts, Commerce and Science, Pune - 411053, India \\ ${ }^{3}$ Botanical Survey of India, Arunachal Pradesh Regional Centre, Itanagar 791111, Arunachal Pradesh, India \\ ${ }^{4}$ Corresponding author; e-mail: ks.rajput15@yahoo.com
}

[Received 14.10.2020; Revised 16.12.2020; Accepted 23.12.2020; Published 31.12.2020]

\begin{abstract}
While revising the genus Tectaria Cav. (Polypodiaceae), in India, 15 species have been recorded from Eastern Himalaya and North East India, of which 11 species are exclusively distributed in this region. On the other hand, T. coadunata, T. fuscipes, T. multicaudata and T. polymorpha are also distributed in different parts of India. In the present paper diversity, distribution, nomenclature, identification key, conservation status and ecology of Tectaria species have been provided.
\end{abstract}

Key words: Tectaria, Biogeography, Identification, Endemic, Hotspot

\section{INTRODUCTION}

The Eastern Himalaya include the entire Arunachal Pradesh and Sikkim states of India, which occupies $2.5 \%$ geographical area. This biogeographic area represents the transition zone between Indo-China-Bhutan region. Similarly, North East India includes Assam, Manipur, Meghalaya, Mizoram, Nagaland and Tripura states of India. It embodies the transition zone between the Indian, Indo-Malayan and Indo-Chinese bio-geographical regions. Therefore, it is one of the biodiversity hotspots which show diverse set of habitats coupled with long term geological stability that has allowed the development of significant levels of endemism in the flora and fauna. (Balasubramanian 2017).

Beddome $(1883,1892)$ explored Eastern Himalaya and North East India and recorded several fern species from Assam and other adjoining regions. Subsequently, Gammie (1895) collected ferns from Lakhimpur district of Assam, Gage (1901) from South Lushi Hills, Burkill from Abor Hills and Bor (1938) from Aka hill. After independence of India, Panigrahi (1960), Panigrahi \& Chowdhury (1961, 1962), Panigrahi \& Patnaik (1961a, 1961b) studied the ferns from North East India and Eastern Himalaya and documented 350 species. Concomitantly, Mehra and Bir (1964) and Hara et al. $(1966,1971)$ studied the pteridophytes diversity of Darjeeling hills. Kachroo (1975) documented fern diversity of Assam including adjoining states like Nagaland, Manipur, Meghalaya and part of Arunachal Pradesh and came up with "Fern flora of Assam" which included phytogeography of 279 species belonging to 104 genera. Thereafter, several pteridologists, studied fern diversity of North East and Eastern Himalaya (Bir et al., 1989; Kachroo et al. 1989; Handique \& Konger 1986; Vasudeva et al. 1990; Fraser-Jenkins 2008; Chandra 2000; Ghosh et al. 2004; Singh \& Panigraphi 2005; Rawat \& Sahu 2009; Benniamin 2010, 2012). Recently, Singh et al. (2012), enlisted total 113 taxa in the Nokrek Biosphere reserve of Meghalaya. Baruwati and Gogoi (2013) studied the pteridophytic flora of Sivasagar district of Assam. Singh et al. (2015) also studied the pteridophytes of Thorangtlang and Tawi Wildlife Sanctuary, Mizoram. Benniamin et al. (2015) added two fern species to the pteridophytic flora 
of Nagaland. Recently, Sharma et al. (2018) have added four species to the pteridophytic flora of Mizoram.

The genus Tectaria Cav. (Polypodiaceae) was known as Aspidium Sw. since long. However, this name was not according to the rules and therefore treated as an illegitimate name. At that time the name Aspidium was used for different genera viz., Dryopteris Adans., Polystichum Roth, or Nephrolepis Schott, (in addition to Tectaria). Therefore, it became the source of confusion. Like other ferns, Tectaria also shows variation in their morphological characters, which led to origin of many new genera such as Sagenia C. Presl, Pleocnemia C. Presl, Dictyopteris C. Presl, Bathmium C. Presl ex Link, Dryomenis Fee ex J. Sm., Podopeltis Fee, Cardiochlaena Fee, and Arcypteris Underw., on the basis of venation characters. Approximately 200 species of Tectaria are accepted worldwide (PPG I), of which twenty-seven species are reported from India (Fraser-Jenkins et al. 2020). In the present investigation authors report fifteen species of Tectaria from Eastern Himalaya and North-East India. Their diversity, distribution conservation status and taxonomic note are given along with identification key to the species occurring in Eastern Himalayas and North-East India.

\section{MATERIAL AND METHODS}

Field visits were carried out during the year 2017 - 2019 in different regions of Eastern Himalaya and North East India. The collected specimens were processed under the laboratory for the preparation of herbariums specimens as per standard methods. Dried herbarium specimens were poisoned using $4 \%$ formalin and affixed on the herbarium sheets by using glue. All the collected specimens were identified using standard literature viz., Panigrahi and Singh, (2005), Patil et al. (2014, 2019a, 2020) and Fraser-Jenkins (2018). The voucher specimens were deposited in BARO herbarium of the Department of Botany, The Maharaja Sayajirao University of Baroda, Vadodara, Gujarat. The conservation status of all the species was studied using IUCN Version 2019-1. Herbarium specimens of all the species reported in the present study are deposited in BARO herbarium of the Maharaja Sayajirao University of Baroda, Vadodara 390002.

\section{RESULTS}

A total of fifteen species viz., Tectaria chattagramica Ching, T. coadunata (J. Sm.) C. Chr, T. decurrens (C. Presl.) Copel., T. fauriei Tagawa, T. fuscipes (Wall. ex Bedd.) C. Chr., T. griffitbii (Baker) C. Chr., T. heterocarpa C.V. Morton, Tectaria impressa (Fée) Holttum, T. ingens (Atk. ex C.B. Clarke) Holttum, T. multicaudata (C.B. Clarke) Ching, T. polymorpha (Wall. ex Hook.) Copel., T. pseudosiifolia Fraser-Jenkins \& Wangadi, T. simonsii (Baker) Ching, T. subconfluens (Bedd.) Ching and T. vasta (Blume) Copel., were collected from Eastern Himalaya and North-East India. The most common species include T. coadunata, T. fuscipes, T. heterocarpa, T. impress, T. polymorpha and T. subconfluens (Figures 1-3).

\section{Key to Specie of Tectaria from Eastern Himalaya and North-East India}

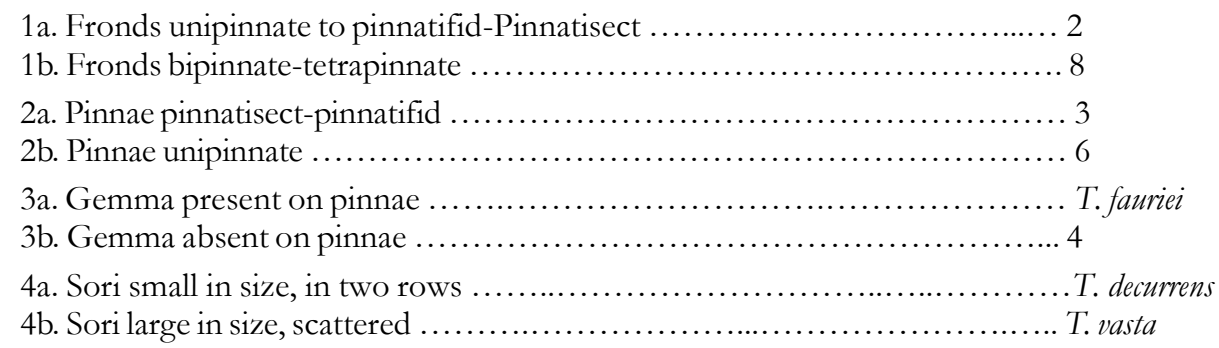


Sachin M. Patil et al. 181
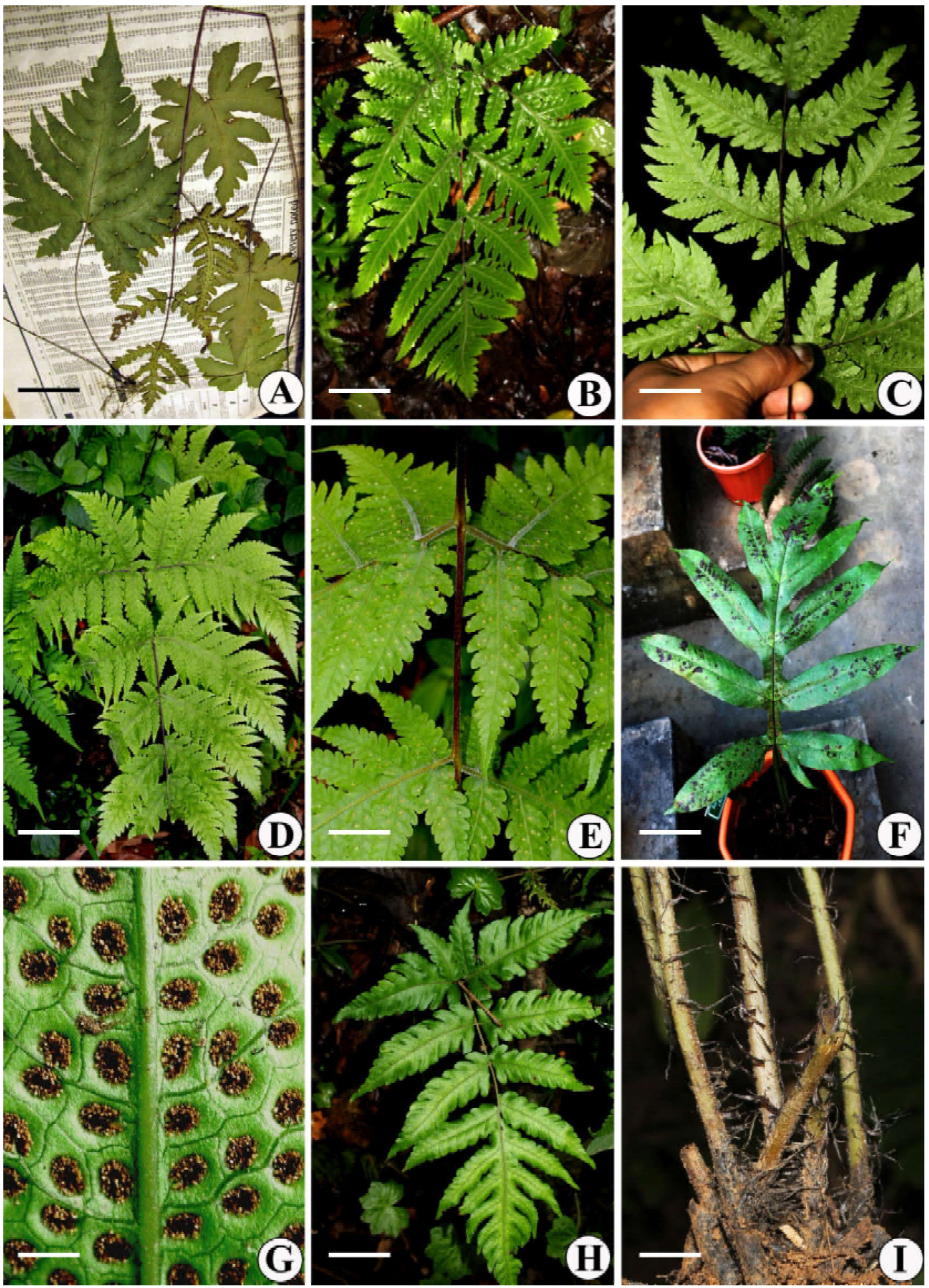

Figure 1: A. Tectaria chattagramica, B. normal T. coadunata, C. enlarged rachis and pinnae of normal $T$. coadunata, D. densely hairy T. coadunata, E. enlarged rachis and pinnae of densely hairy T. coadunata, F. T. decurrens, $\mathbf{G}$. Sori of T. decurrens, $\mathbf{H}$. T. fuscipes, $\mathbf{I}$. dark black scale of T. fuscipes.

Sacle Bar: A-F $\boldsymbol{\&} \mathbf{H}=5 \mathrm{~cm}, \mathbf{G}=5 \mathrm{~mm} \boldsymbol{\&} \mathbf{I}=1 \mathrm{~cm}$ 
5a. Stipe, rachis and costa with densely hairy ....

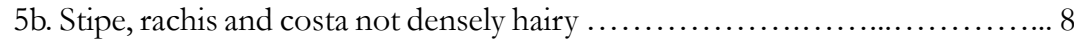

6a. Pinnae without axil bulbils ......................................... 7

6b. Pinnae with axil bulbils ............................................. heterocarpa

7a. Lower pinnae bifurcate ........................................... T. polymorpha

7b. Lower pinnae bipinnate-pinnatifid .................................. simonsii

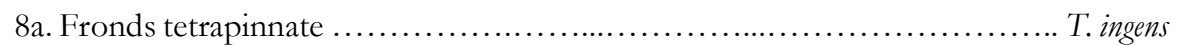

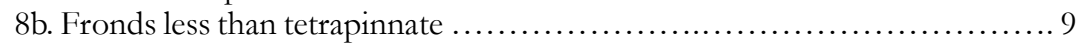

9a. Veins free with coastal areoles ....................................... fuscipes

9b. Veins anastomosing ........................................... 10

10a. Plant dimorphic .....................................................

10b. Plant monomorphic or subdimorphic ............................ 13

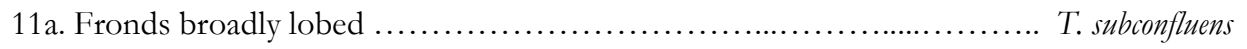

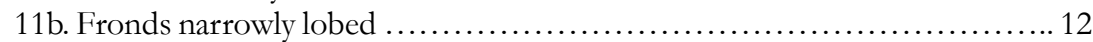

12a. Lower pinnae lacking free pinnules ............................... Thattagramica

12b. Lower pinnae having free pinnules $\ldots \ldots \ldots \ldots \ldots \ldots \ldots \ldots \ldots \ldots \ldots \ldots \ldots \ldots \ldots \ldots$. impressa

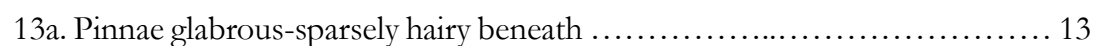

13b. Pinnae sparsely-densely hairy beneath ........................... T. coadunata

14a. Costa and costule areole absent .................................. griffithii

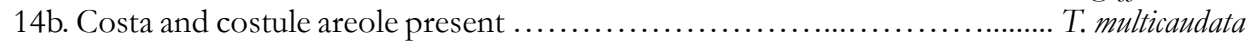

1. Tectaria chattagramica (C.B. Clarke) Ching, Sinensia 2: 35, t. 14.1931.

Lectotype, BANGLADESH, Chittagong (Dist.), Burkhul, 250 ft., 12/2/1873, C. B. Clarke (19879A), K001080708.

Distribution: World: Bangladesh, Myanmar, India and Thailand. INDIA: Assam, Sikkim, Manipur, Meghalaya, Mizoram, Sikkim and Tripura.

Eastern Himalaya: Sikkim

North-East India: Assam, Manipur, Meghalaya, Mizoram, Sikkim and Tripura.

Conservation Status: T. chattagramica is collected from North-East and Eastern Himalaya along the cut edges or hilly slopes. A population of $50-100$ individuals were observed per square kilometre and the area of occupancy (AOO) is $200-400 \mathrm{~km}^{2}$. Therefore, as per IUCN categories and criteria (IUCN ver. 2017-1), it is assessed as least concerned (LC) species for North-East and Eastern Himalayas of India.

Ecology: Uncommon species collected an altitude $<300 \mathrm{~m}$ (rarely up to $500 \mathrm{~m}$ ) along the roadside, cut edges, or dense to dry deciduous forest growing below $<25{ }^{\circ} \mathrm{C}$ temperature and $>50 \%$ atmospheric humidity.

Specimen Examined: India - Assam, Karbi Anglong dt., Nambar forest, near the hot springs, 01/1890, Beddome, R.H (\#s.n.) K001080710; Kamrup Metropolitan dt., Garbhanga, 210 m, 26/02/2018, S. M. Patil (3001) BARO; BANGLADESH: Chittagong (Dist.), Kasalong, 10/ 01/1869, C.B. Clarke, (177) K001080707; Ruttumpoea, 07/02/1873, C.B. Clarke, (19767) K001080709.

2. Tectaria coadunata (J.Sm.) C. Chr., Contrib. U. S. Natl. Herb. 26 (6): 331. 1931.

Lectotype, NEPAL, Kathmandu (Dist.), Hetauda \& Bhimphedi, 1820, N. Wallich (377.1), K001080706.

World: Bhutan, China, India, Malaysia, Myanmar, Nepal, Sri Lanka, Thailand, Vietnam, Africa, Madagascar. INDIA: Throughout. 

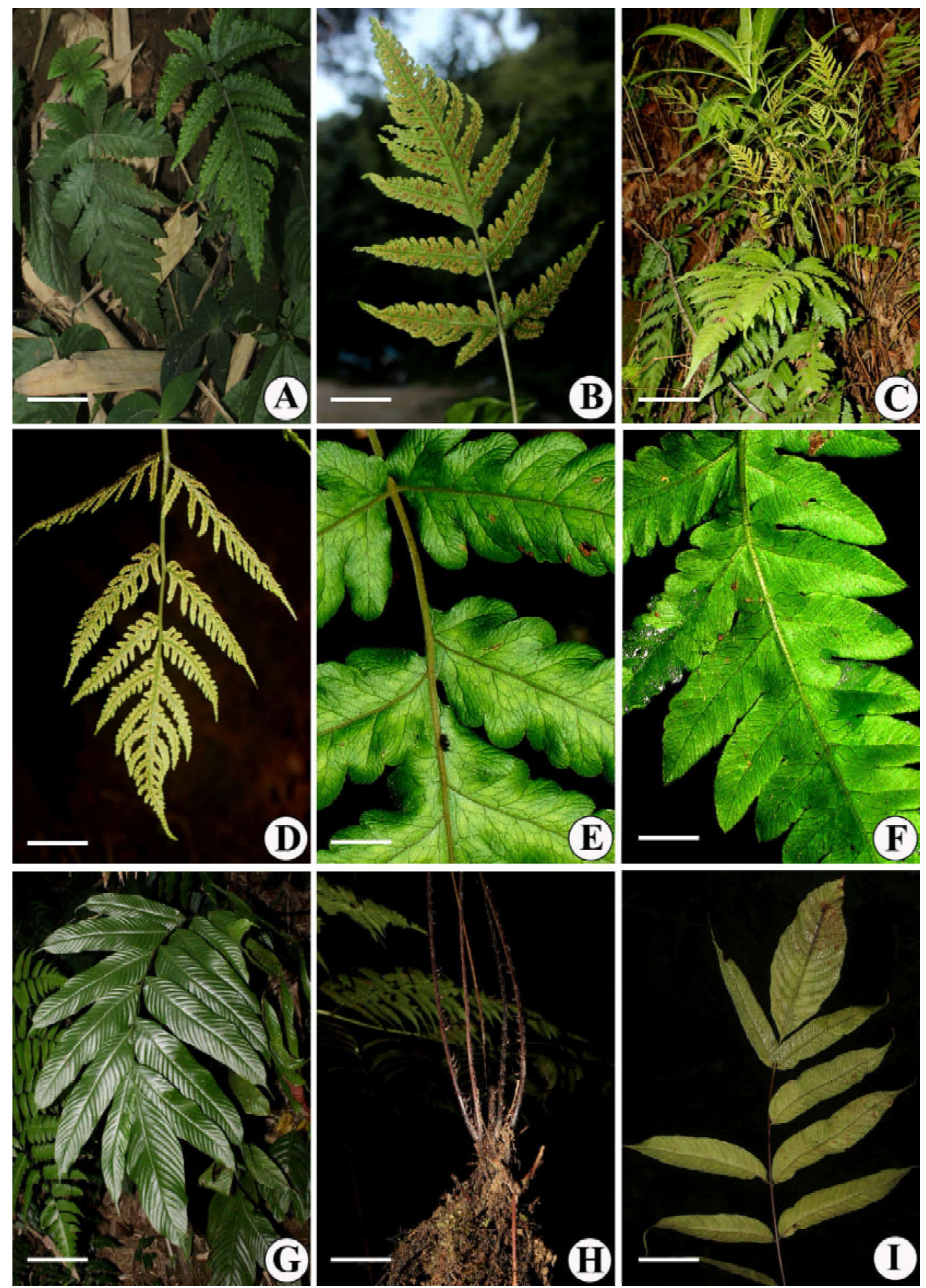

Figure 2: A-D. varitions within the fertile fronds of Tectaria fuscipes, E. enlarged pinnae of T. fuscipes showing costal areole, $\mathbf{F}$. enlarged pinnae of T. fuscipes without costal areole, G-I. habit, rhizome and fertile frond of T. heterocarpa respectively. Sacle Bar: A, C, G, $\mathbf{I}=5 \mathrm{~cm}, \mathbf{B}, \mathbf{D}, \mathbf{H}=3 \mathrm{~cm} \boldsymbol{E} \mathbf{E}, \mathbf{F}=1 \mathrm{~cm}$ 
Eastern Himalaya: Arunachal Pradesh and Sikkim

North-East Indian: Assam, Manipur, Meghalaya, Mizoram, Nagaland and Tripura.

Conservation Status: T. coadunata is collected from different localities in Eastern Himalaya and North-East India. A population of 100-200 individuals were observed per square kilometre and the area of occupancy (AOO) is $300-500 \mathrm{~km}^{2}$. Therefore, as per IUCN categories and criteria (IUCN ver. 2017-1), it is assessed as least concerned (LC) species for North-East and Eastern Himalayas of India.

Ecology: Most common species collected above $>500 \mathrm{~m}$ from different habitats viz., along the roadside, hilly slopes, cut edges, in dense to dry deciduous forest or along the water channels and rivers, growing up to $35^{\circ} \mathrm{C}$ temperature and $30 \%$ atmospheric humidity.

Specimen Examined: INDIA - Arunachal Pradesh, Papam Pare dt., Ganga Lake, Itanagar, 230 m, 14/02/2018, S. M. Patil (3003) BARO; Upper Subansiri District, 10.06.2008, A. Benniamin (22759) ARUN12556; Dibang Valley Dt., Checkopani-Tiwarigoan Road, Mehao Wildlife Sanctuary, 17.11.2000, A. Benniamin (9206) ARUN; Assam, Kamrup Metropolitan dt., Kamakya Temple road, 210 m, 26/02/2018, S. M. Patil (3004) BARO; Meghalaya, North Khasi Hills, Nongpoh, 520 m, 19/02/2018, S. M. Patil (3005), BARO; Mizoram, Mamit dt., Dampa Tiger Reserve, A. Benniamin (28481) ARUN 14877; Maharashtra, Satara Dt, Mahabaleshwar, alt. 1000 m., 26/12/1964, M. R. Almeida BLAT 248; Karnataka, North Kanara, Castle Rock, 03/ 01/1966, M. R. Almeida BLAT 804; Andhra Pradesh, East Godavari Dt., Maredumilth, tiger camp, alt. 1200 m., 17/08/1995, Mohanan MH105036.

3. Tectaria decurrens C. Presl, Reliq. Haenk. 1: 28. 1825.

Holotype, PHILIPPINES, Luzon, Sorzogon, T. Haenke, herb. C. Presl

Distribution: World - Bangladesh, China, India, Indonesia, Japan, Laos, Malaysia, Myanmar, Nepal, Philippines, Sri Lanka, Taiwan, Thailand, Vietnam. INDIA: Andaman \& Nicobar Islands, Arunachal Pradesh, Assam, Meghalaya and Tamil Nadu.

Eastern Himalaya: Arunachal Pradesh

North-East India: Assam and Meghalaya.

Conservation Status: T. decurrens is collected from different localities in Eastern Himalaya and North-East India. A population of 50-100 individuals were observed per square kilometre and the area of occupancy (AOO) is $300-500 \mathrm{~km}^{2}$. Therefore, as per IUCN categories and criteria (IUCN ver. 2017-1), it is assessed as least concerned (LC) species for North-East and Eastern Himalaya of India.

Note: Uncommon fern collected at an altitude $<1500 \mathrm{~m}$ (rarely up to $2000 \mathrm{~m}$ ) along the water current or streams in dense forest areas, growing below $<25^{\circ} \mathrm{C}$ temperature and $>50 \%$ atmospheric humidity.

Specimens Examined: India - Meghalaya, East Khasi Hills dt., Shillong, Elephant falls, 12.10.2010, A. Benniamin (26160), ARUN; Arunachal Pradesh, West Siang dt., Kane WLS, S. S. Dash (32255) ARUN 20994.

4. Tectaria fauriei Tagawa, J. Jap. Bot. 14(2): 102-104. 1938.

Holotype, TAIWAN, Pere U.J. Faurie 67, KYO.

Distribution: World - China, India, Japan, Malaysia, Myanmar, Taiwan, Thailand, Vietnam. INDIA: Arunachal Pradesh, Assam, Meghalaya.

Eastern Himalaya: Arunachal Pradesh. 

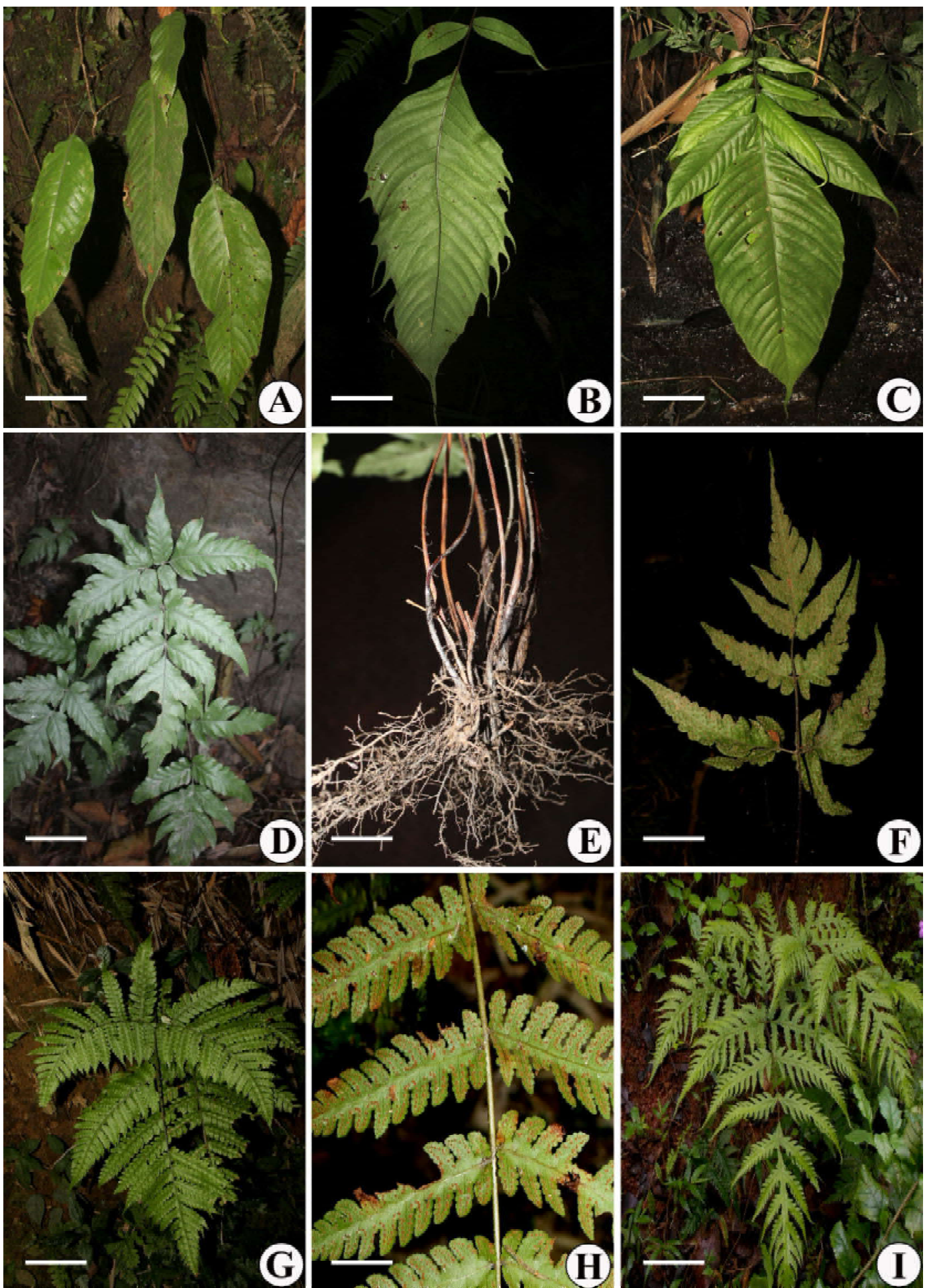

Figure 3: A-C. range of variation in T. heterocarpa, D-F. habit, rhizome and fertile frond of T. impressa respectively, G-H. habit and fertile frond of T. ingens, I. T. multicaudata.

Sacle Bar: A-D G, $\mathbf{I}=3 \mathrm{~cm} \& \mathbf{E}, \mathbf{F}, \mathbf{H}=1 \mathrm{~cm}$ 
North-East India: Assam and Meghalaya.

Conservation Status: T. fauriei is reported from North East India and Eastern Himalaya. Authors have not collected this species, however, it was listed in recent literature hence documented here. At present, as per IUCN categories and criteria (IUCN ver. 2017-1), it is assessed as data deficient (DD) species for Eastern Himalayas and North East India.

Note: Uncommon fern collected at an altitude $<1500 \mathrm{~m}$ (rarely up to $2000 \mathrm{~m}$ ) along the water current or streams in dense forest areas, growing below $<25^{\circ} \mathrm{C}$ temperature and $>50 \%$ atmospheric humidity.

5. Tectaria fuscipes (Wall. ex Bedd.) C. Chr., Contr. U.S. Natl. Herb. 26: 290. 1931.

Lectotype, INDIA, Assam State, Cachar Hills, C. B. Clarke (7050). K001080698

World: Bangladesh, Bhutan, China, India, Indonesia, Myanmar, Nepal, Taiwan, Thailand, Tibet and Vietnam. INDIA: Arunachal Pradesh, Assam, Karnataka, Manipur, Mizoram, Meghalaya, Nagaland, Sikkim, Tripura, West Bengal.

Eastern Himalaya: Arunachal Pradesh.

North-East India: Assam, Manipur, Mizoram, Meghalaya, Nagaland, Sikkim, Tripura

Conservation Status: T. fuscipes is collected from different forest regions of North East India and Eastern Himalaya. A population of $200-300$ individuals were observed per square kilometre and the area of occupancy (AOO) is $500-700 \mathrm{~km}^{2}$. At present, as per IUCN categories and criteria (IUCN ver. 2017-1) it is assessed as least concerned (LC) for North-East and Eastern Himalaya of India.

Note: It is an uncommon species found below $1200 \mathrm{~m}$ altitude (rarely $>1500 \mathrm{~m}$ ) collected along the roadside or water current, growing below $<25^{\circ} \mathrm{C}$ temperature and $>50 \%$ atmospheric humidity.

Specimens Examined: India - Arunachal Pradesh, Lower Subansiri dt., Doimukh forest, 13.11.1978, G. D. Pal (70230) ARUN; Upper Subansiri dt., Pasighat Forest Area, 12.07.2008, A. Benniamin (22543) ARUN12505; Tripura, Dumpur Forest Area, 18.06.2011, A. Benniamin (28192) ARUN14143; Arunachal Pradesh, Papam Pare dt., Itanagar, 210 m, 12/02/2018, S. M. Patil (3008) BARO; Meghalaya, North Khasi Hills dt., Nongpoh, 550 m, 19/02/2018, S. M. Patil (3009) BARO; Assam, Kamrup Metropolitan dt., Kamakya temple road, 230 m, 26/02/ 2018, S. M. Patil (3010) BARO; Mizoram, Aizawal dt., Tawi Wildlife Sanctuary, 09.11.2011, A. Benniamin (28568) ARUN15459; Manipur, Tamenglong dt., 28.09.2012, A. Benniamin (28883 A) ARUN20754.

6. Tectaria griffithii (Baker) C. Chr., Index Fil. Suppl. 3: 180. 1934.

Holotype, MYANMAR, W. Griffith, K001080693.

World: Bangladesh, Cambodia, China, India, Laos, Malaysia, Myanmar, Philippines, Taiwan, Thailand and Vietnam. INDIA: Arunachal Pradesh, Assam, Nagaland, Tripura.

Eastern Himalaya: Arunachal Pradesh.

North-East India: Assam, Tripura

Conservation Status: T. griffithii is reported from Eastern Himalaya and North-East India. Authors have not collected this species, however, specimens are available in herbaria and also listed in recent literature hence documented here. At present, as per IUCN categories and criteria (IUCN ver. 2017-1), it is assessed as data deficient (DD) species for Eastern Himalayas and North East India. 

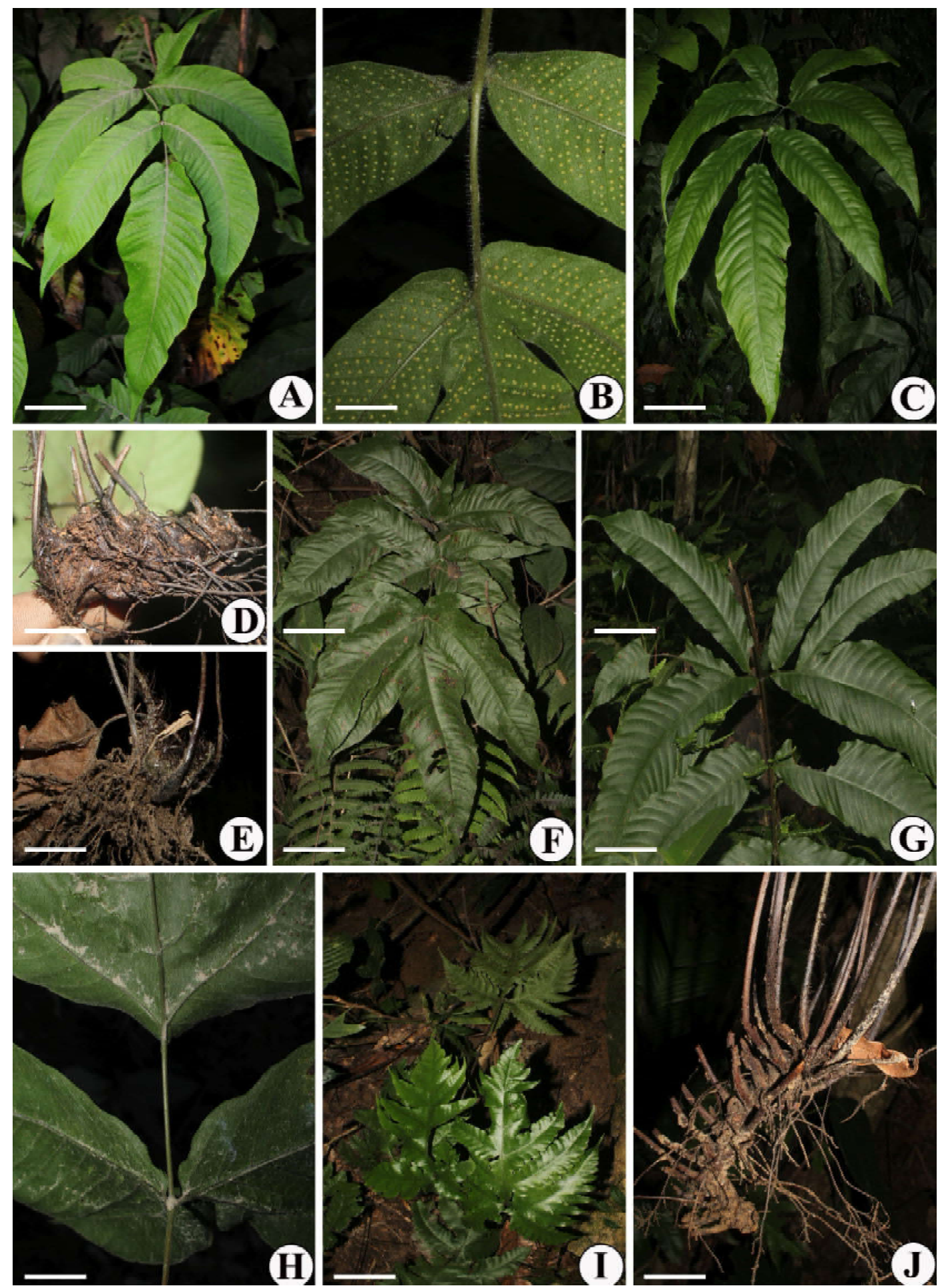

Figure 4: A. Tectaria spendosiifolia, B. densely hairy rachis \& pinnae of T. psendosiifolia, $\mathbf{C}$. normal habit of $T$. polymorpha, D-E. variations in rhizome structure of T. polymorpha (long \& short creeping respectively), F-H. range of variations in frond of T. polymorpha (bifurcate each pinnae, tetrafurcate basal pinne and enlarged portion of rachis and pinnae rerespectively), I-J. habit and rhizome of T. subconfluens.

Sacle Bar: A, C, F, I = $3 \mathrm{~cm}, \mathbf{B}, \mathbf{D}, \mathbf{E}, \mathbf{G}, \mathbf{H}, \mathbf{J}=1 \mathrm{~cm}$ 
Note: It is an uncommon species found $<1200 \mathrm{~m}$ altitude collected along the roadside or water current, growing below $<25{ }^{\circ} \mathrm{C}$ temperature and $>50 \%$ atmospheric humidity.

Specimens Examined: India - Arunachal Pradesh, Lower Subansiri dt., On the way to Old Ziro, (Arunachal Pradesh), 04.06.2008, A. Benni. (22886) ARUN12586; Kurung Kumey dt., Koloriang, 07/12/2008, A. Benni. (26424) ARUN 12590; Lower Dibang Valley dt., Mayodia pass, $12 /$ 06/2010, A. Benni (26863) ARUN 12584.

7. Tectaria heterocarpa (Bedd.) C. V. Morton, Contrib. U. S. Natl. Herb. 38 (6): 270. 1973. Holotype, INDIA, Meghalaya, Khasi Hills, Dr. T. Thomson, Herb. Beddome, K.

World: Bangladesh, India, Myanmar, Nepal. INDIA: Arunachal Pradesh, Assam, Meghalaya, Mizoram, Nagaland, Tripura, West Bengal, Tripura.

Eastern Himalaya: Arunachal Pradesh.

North-East India: Assam, Meghalaya, Mizoram, Nagaland, Tripura, Tripura.

Conservation Status: T. heterocarpa is collected from different regions of North-East and Eastern Himalaya. A population of $100-200$ individuals were observed per square kilometre and the area of occupancy (AOO) is $100-250 \mathrm{~km}^{2}$. Therefore, as per IUCN categories and criteria (IUCN ver. 2017-1), it is assessed as least concerned (LC) for Eastern Himalayas and North East India.

Note: It is a common species found below $800 \mathrm{~m}$ altitude (rarely up to $1000 \mathrm{~m}$ ) collected along the cut edges or hill slopes and water current, growing below $<25^{\circ} \mathrm{C}$ temperature and $>40 \%$ atmospheric humidity.

Specimens Examined: India, Arunachal Pradesh, Papumpare dt., Itanagar, 400-500 m alt., 17/02/ 2018, S. M. Patil \& K. S. Rajput 3015 (BARO); Naharlagun Dam Site, 06.11.1978, G.D. Pal 70147 (ARUN); Ganga Lake, Itanagar, 25.01.2009, CRFJ \& A. Benni. 33616 (ARUN); Tripura, North Tripura dt., Kanchanpur forest Area, 04.07.2011, A. Benni. 28227 (ARUN); Dumpur forest Area, 15.06.2011, A. Benni. (28184) ARUN14548; Mizoram, 03.11.2011, A. Benni. 28438 (ARUN).

8. Tectaria impressa (Fee) Holttum, Kew Bull. 43(3): 483. 1988.

Lectotype INDIA, Meghalaya, W. Griffith 34

World: Bangladesh, Cambodia, China, India, Indonesia, Laos, Malaysia, Myanmar, Taiwan, Thailand, Vietnam. INDIA: Assam, Meghalaya, Mizoram, Nagaland, Tripura, West Bengal, Tripura.

North-East India: Assam, Meghalaya, Mizoram, Nagaland, Tripura, Tripura.

Conservation Status: T. impressa is collected from different regions of North-East and Eastern Himalayas. A population of 100-150 individuals were observed per square kilometre and the area of occupancy is $200-400 \mathrm{~km}^{2}$. Therefore, as per IUCN categories and criteria (IUCN ver. 2017-1), it is assessed as least concerned (LC) for North-East and Eastern Himalayas of India.

Note: It is a common species found below $600 \mathrm{~m}$ altitude, collected along the cut edges along the roadside or hilly slopes and water current, growing below $<25^{\circ} \mathrm{C}$ temperature and $>40 \%$ atmospheric humidity.

Specimens Examined: India, Assam, Kamrup Metropolitan dt., Kamakhya temple road, $200 \mathrm{~m}$ alt., 26/10/2018, S. M. Patil and K. S. Rajput (3023) BARO12345700103; Guwahati, Zoo cum Botanical Garden, $300 \mathrm{~m}$ alt., 26/10/2018, S. M. Patil and K. S. Rajput (3024) 
BARO12345700104; Meghalaya, Shilong to Nongpoh road, $500 \mathrm{~m}$ alt., 27/02/2018, S. M. Patil and K. S. Rajput (3025) BARO12345700105.

9. Tectaria ingens (Atk. ex C.B. Clarke) Holttum, Revis. Fl. Malaya 2: 503. 1955.

Lectotype, INDIA, West Bengal, Darjeeling, Rungbee, 3000 ft., 27.9.1869, C.B. Clarke 9295 (K). World: Bangladesh, Bhutan, China, India, Nepal, Tibet, Vietnam. INDIA: Arunachal Pradesh, Manipur, Meghalaya, Mizoram, Nagaland, Sikkim, West Bengal.

Eastern Himalaya: Arunachal Pradesh, Sikkim, West Bengal.

North-East India: Manipur, Meghalaya, Mizoram, Nagaland.

Conservation Status: T. ingens is collected from different regions of North-East and Eastern Himalaya. A population of 100 - 150 individuals were observed per square kilometre and the area of occupancy (AOO) is $100-250 \mathrm{~km}^{2}$. Therefore, as per IUCN categories and criteria (IUCN ver. 2017-1), it is assessed as least concerned (LC) for North-East and Eastern Himalayas.

Note: It is a common species found below $700 \mathrm{~m}$ altitude, collected along the forest floor or hilly slopes growing below $<25^{\circ} \mathrm{C}$ temperature and $>60 \%$ atmospheric humidity.

Specimen Examined: India, Arunachal Pradesh, Papam Pare Dist., Ganga Lake, 20/02/2018, S. M. Patil \& K.S. Rajput, 3026 (BARO).

10. Tectaria multicaudata (C.B. Clarke) Ching, Sinensia 2: 20. 1931.

Holotype, BANGLADESH, Sylhet, 250 ft., 30.11.1872, C.B. Clarke 18427C, K.

Distribution: World: Bangladesh, India, Malaysia, Myanmar, Nepal, Thailand. INDIA: Arunachal Pradesh, Assam, Maharashtra, Meghalaya and Sikkim.

Eastern Himalaya: Arunachal Pradesh, Sikkim.

North-East India: Assam, Meghalaya.

Conservation Status: T. multicaudata is collected from different regions of North-East and Eastern Himalayas. A population of 100-150 individuals were observed per square kilometre and the area of occupancy (AOO) is $100-250 \mathrm{~km}^{2}$. Therefore, as per IUCN categories and criteria (IUCN ver. 2017-1), it is assessed as least concerned (LC) for North-East and Eastern Himalayas.

Specimens Examined: India, Maharashtra, Kolhapur Dt., Panhala, alt. 800 m, 13/08/2018, S. M. Patil \& K. S. Rajput 3036, BARO; Tripura, North Tripura Dt., Churaibari, alt. 600 m, $18 /$ 06/2011, A. Benniamin 28203, 22886, 26424, 14687, ARUN.

11. Tectaria polymorpha (Wall. ex Hook.) Copel. Philipp. J. Sci., Sect. C, Botany 2:413. 1907; Christensen, Contr. U.S. Natl. Herb. 26: 330. 1931; Sledge, Kew Bull. 27:419 (1972) \& Bot. J. Linn. Soc. 84:18 (1982); Nayar \& Kaur, Comp. Bedd., Handb. 51(1974); Dixit, Census 144 (1984); Rajagopal \& Bhat, Indian Fern J. 15:21 (1998).

Lectotype, NEPAL, N. Wallich Num. List no. 382, K

Distribution: World: Bangladesh, Bhutan, Cambodia, China, India, Indonesia, Myanmar, Nepal, Philippines, Sri Lanka, Taiwan, Thailand, Vietnam. INDIA: Throughout

Eastern Himalaya: Arunachal Pradesh, Sikkim.

North-East India: Assam, Meghalaya, Mizoram, Nagaland, Tripura and Manipur

Conservation status: T. polymorpha is collected from different North-East India, Eastern Himalaya and Western Ghats. About 100-200 individuals were observed per square kilometre and the 
area of occupancy (AOO) is $400-500 \mathrm{~km}^{2}$. Therefore, as per IUCN categories and criteria (IUCN ver. 2017-1), it is assessed as least concerned (LC) species for North-East and Eastern Himalaya of India.

Note: It is a common species found at an altitude the $100-1200 \mathrm{~m}$ (rarely $>1200 \mathrm{~m}$ ), collected along the roadside, growing in rock crevices or on cutting edges at temperature $<25{ }^{\circ} \mathrm{C}$ and $>50 \%$ atmospheric humidity.

Specimens Examined: India, Karnataka, Dt., North Kananda, Castle Rock alt., 1100 m, 13/08/ 2018, S. M. Patil \& K. S. Rajput 3041, BARO; Dt., Udupi, Sringeri, alt., 300 m, 08/06/2018, S. M. Patil \& K. S. Rajput 3042, BARO; Arunachal Pradesh, Dt., Papam Pare, Itanagar, Ganga Lake, 18/02/2018, S. M. Patil \& K. S. Rajput 3043, BARO; Meghalaya, Jowai Hills, 26/02/ 2018, S. M. Patil \& K. S. Rajput 3043, BARO; Dawki, 03/06/2019, S. M. Patil \& K. S. Rajput 3044, BARO; Assam (NEFA), Foothill Camp, alt., 800 m, G. Panigrahi, 5830A (ASSAM); Tripura, Dt., North Tripura, Jampui Hills, alt., 900 m, 26/06/2011, A. Benniamin, 28249 (ARUN); Mizoram, Dampa Tiger reserve, alt., 900 m, 03/11/2011, A. Benniamin, 28441 (ARUN).

12. Tectaria pseudosiifolia Fraser-Jenk. \& Wangdi, Fraser-Jenkins, Kandel \& Pariyar, Ferns Fern-allies Nepal 1: 31. 2015.

Holotype, BHUTAN, $3 \mathrm{~km} \mathrm{~N}$. of Samdrup Jongkhar, $2 \mathrm{~km} \mathrm{~S}$. of Pinchinang Check-post, C.R. Fraser-Jenkins, T. Wangdi, S. Lungten \& T. Dorji 33930 (FN 16), 20.5.2009, TAIF.

Distribution: World: Bhutan, India. INDIA: Arunachal Pradesh, Sikkim, Meghalaya.

Eastern Himalaya: Arunachal Pradesh, Sikkim.

Conservation status: T. pseudosiifolia, is collected from Eastern Himalaya's only. About 100-200 individuals were observed per square kilometre. However, other forest areas of India are yet to be explored thoroughly and more floristic explorations are needed to determine and document the full range of distribution. Therefore, as per IUCN categories and criteria (IUCN ver. 2017-1), it is assessed as data deficient (DD).

Note: It is a unique species found at an altitude the below $1200 \mathrm{~m}$ (rarely $>1200 \mathrm{~m}$ ), collected along the roadside, growing on cutting edges at temperature $<25^{\circ} \mathrm{C}$ and $>50 \%$ atmospheric humidity.

Specimens Examined: Arunachal Pradesh, Dt., Papam Pare, Itanagar, Ganga Lake, 18/02/2018, S. M. Patil \& K. S. Rajput 3034 (BARO); Sanki Park, 21/02/2018, S. M. Patil \& K. S. Rajput 3035 (BARO); Naharlagun to Ziro road, 02/12/2018, S. M. Patil \& K. S. Rajput 3035 (BARO); Subansiri dt., Ziro, 31/05/2008, A. Benni. 12861 (ARUN); West Siang dt., On the way of Mechuka-tato, 20/11/2008, A. Benni. 12864 (ARUN); Upper Siang dt., Megging to tuting road, 18/01/2013, A. Benni., 20252 (ARUN).

13. Tectaria simonsii (Baker) Ching, Sinensia 2(2): 32 - 33, t. 8. 1931.

Lectotype, INDIA, Assam or Nagaland, "Mikir ["Nuku Hills" of Holttum (1981)] and Naga Hills", C.J. Simons 301, Jany. (c. 1853), K.

Distribution: Bangladesh, China, India, Japan, Malaysia, Myanmar, Taiwan, Thailand, Vietnam. INDIA: Arunachal Pradesh, Assam, Meghalaya, Nagaland and Sikkim

Eastern Himalaya: Arunachal Pradesh, Sikkim

North-East India: Assam, Meghalaya, Nagaland.

Conservation status: T. simonsii, is reported from North-East India and Eastern Himalaya. Authors have not collected this species however specimens are available in herbaria and also listed in 
recent literature hence documented here. At present, as per IUCN categories and criteria (IUCN ver. 2017-1), it is assessed as data deficient (DD) species for Eastern Himalaya and North East India.

Note: It is a unique species found along the roadside, growing on cutting edges or in rock crevices.

Specimens Examined: Arunachal Pradesh, Dt., Papam Pare, Itanagar, Sanki Park, 21/02/2018, S. M. Patil \& K. S. Rajput 3048 (BARO); Papampare Dt., Doimukh, 13/11/1978, G. D. Pal 702229 (ARUN); Assam, Sonitpur Dt., Potasali, 17/02/1957, G. Panigrahi, 5287.

14. Tectaria subconfluens (Bedd.) Ching, Sinensia 2: 27, t. 8. 1931.

Holotype, INDIA, Meghalaya, Khasi Hills, below Umwai, 3000 ft., C.B. Clarke [19340A, 7.11.1872], herb. R.H. Beddome, K.

Distribution: Bangladesh, India. INDIA: Arunachal Pradesh, Assam State, Meghalaya.

Eastern Himalaya: Arunachal Pradesh, Sikkim

North-East India: Assam, Meghalaya, Nagaland,

Conservation status: T. subconfluens, is reported from North-East India and Eastern Himalaya. About 100-200 individuals were observed per square kilometre and the area of occupancy (AOO) 100-200 km². Therefore, as per IUCN categories and criteria (IUCN ver. 2017-1), it is assessed as Vulnerable (VL) species for North-East and Eastern Himalayas of India.

Note: It is a unique species found along the roadside, growing on cutting edges or in rock crevices.

Specimens Examined: Arunachal Pradesh, Dt., Papam Pare, Itanagar, Sanki Park, 21/02/2018, S. M. Patil \& K. S. Rajput 3048 (BARO); Ganga Lake, 21/02/2018, S. M. Patil \& K. S. Rajput 3048 (BARO); Itanagar lake area, 19/04/1985, B. Ghosh 59690 (CNH); Kameng, 21/11/ 1970, A. S. Rao 50525 (CNH); West Siang dt., On the way of Mechuka-tato, 20/11/2008, A. Benni. 20341 (ARUN).

15. Tectaria vasta (Blume) Copel., Philipp. J. Sci. 2(6): 411. 1907.

Holotype, INDONESIA, Java, C.L. von Blume, L.

Distribution: Bangladesh, China, India, Indonesia, Laos, Malaysia, Myanmar, Thailand, Vietnam. INDIA: Andaman \& Nicobar Islands (Nicobars), Arunachal Pradesh, Assam State, Manipur, Meghalaya, Mizoram, Nagaland and Tripura

Eastern Himalaya: Arunachal Pradesh

North-East India: Assam, Meghalaya, Nagaland,

Conservation status: T. vasta is reported from North-East India and Eastern Himalaya. Authors have not collected this species, however, specimens are available in herbaria and also listed in recent literature hence documented here. At present, as per IUCN categories and criteria (IUCN ver. 2017-1), it is assessed as data deficient (DD) species for Eastern Himalayas and North East India.

Note: It is a unique species found along the water channels at an elevation $300-800 \mathrm{~m}$.

Specimens Examined: India, Assam, Cachar Dt., Bihara, 06/10/2011, HAB 700 (ASSAM); Arunachal Pradesh, Upper Subansiri dt., 26/09/1959, Panigrahi 19578 (ASSAM); Upper subansiri dt., A. Benni., 22707 (ARUN); Changlang dt., Diban bulbulia briddle path, G.D. Pal, 7376 (ARUN); West Siang dt., Kane Wildlife Sanctuary, S.K. Das, 20994 (ARUN). 


\section{DISCUSSION}

On the basis of morphology, all the collected species of Tectaria are grouped into three complexes (Patil et al. 2019a). The complex-I includes the species which having uni-pinnate, pinnatifid or pinnatisect fronds with highly anastomosing veins with branched included veinlets viz., Tectaria decurrens, T. fauriei T. heterocarpa, T. polymorpha, T. pseudosiifolia and T. vasta. The complex-II includes the species having bipinnate to tripinnate or tripinnatifid fronds with partly anastomosing veins with or without unbranched included veinlets viz., Tectaria chattagramica, $T$. coadunata, T. griffitbii, T. impressa, T. multicaudata, T. simonsii and T. subconfluens. The complex-III includes the species which are having bipinnate to tetrapinnate fronds with free veins without included veinlets viz., Tectaria fuscipes and T. ingens.

Amongst these 11 species vi\%, Tectaria decurrens, T. fauriei, T. heterocarpa, T. ingens, T. pseudosiifolia, Tectaria chattagramica, T. griffithii, T. impressa, T. simonsii and T. subconfluens are restricted in this region. The most common species are T. coadunata, T fuscipes, T. heterocarpa T. impressa and T. polymorpha. Leaf morphology along with venation pattern was studied by Sledge (1972), Salgado (1982) and Holttum (1983). Salgado (1982) made a detailed study on the venation patterns of tectarioid ferns of Phillipines. Banerjee (Mukherjee) and Mukhopadhyay (2008) also made a detailed study on the venation patterns of 22 Indian tectarioid ferns. They designated four different types of venation patterns, out of which the free veined type was marked as the primitive type and the reticulate type with included veinlets which may be branched or unbranched.

T. chattagramica is characterised by short creeping rhizome, fronds clustered, dimorphic, lamina bipinnate-bipinnatifid, pubescent, basal pinnae deeply lobed of which the basal lobe at the basiscopic side is comparatively larger, veins anastomosing, basal portion of the pinnae forming few, large, areoles without any included veinlets, sori scattered, situated on apical free portion of veins (Figure 1A). As shown in Figure 1B-E, Tectaria coadunata collected from north-east and Himalayan regions are either less hairy or densely hairy and having less dissected lamina. Hence, north east and eastern Himalayan T. coadunata is misreported as T. cicutaria and T. macrodonta by Vasudeva et al. (1990), Borthakur et al. (2000) and, Singh and Panigrahi (2005). The T. decurrens is wrongly identified as Leptochilus insignis (= Microsorum insigne) by Balakrishnan (Bull. Bot. Surv. India 22(1-4): 136-137. 1981) and Dixit \& Sinha (Pterid. Andaman Nicobar Isl. 48. 2001), because of similar sterile fronds phyllotaxy (Figure 1F-G). Its occurrence is also documented in South India, which is based on single specimen deposited at Kew by Beddome. Later on, Indian pteridologists have usually not mentioned South India in its range (Fraser-Jenkins 2018). Tectaria decurrens is smaller in size than T. vasta and has large sized sori, arranged in definite manner with large, elliptical indusia. T. fauriei is a little-known species often misreported or overlooked as T. vasta because having simple or pinnatisect, decurrent lamina. However, presence of axillary gemma on the lamina makes different from the T. vasta (Fraser-Jenkins et al 2018).

T. fuscipes is characterised by presence of erect to suberect rhizome, dark black scales, dimorphic fronds, fertile fronds longer and narrow than sterile one (Figure 1H-I and Figure 2 A-F). However, it was collected from Dawki, Jawoi Hills, Nangpoh, Ganga Lake and some collection of Dr. A. Benniamin from Tripura and Mizoram doesn't have costal or costular areole (Figure 2E-F) but they are having dark black scales of typical T. fuscipes types (Figure 1I). Due to lack of costal and costular areole, Vasudeva et al. (1990) and Borthakur et al. (2000) identified it as T. paradoxa. Moreover, it also shows fertile lamina is broad as sterile one whereas in some, having very narrow fertile lamina (Figure $2 \mathrm{~B} \& \mathrm{D}$ ).

According to Patil et al. (2020) many collections deposited in ASSAM and ARUN herbaria under the name Tectaria griffithii is of T. multicaudata. Both the species having difference 
in scale distribution pattern, phyllotaxy, costal and costular areole (Patil et al. 2020). In T. griffitbii the stipe is scaly only at the base, it has alternate to-subopposite phyllotaxy and costal and costular areoles are absent whereas in T. multicaudata, the stipe scaly up to rachis or even up to costa, has opposite to subopposite phyllotaxy and costal and costular areoles are present, which differentiate the T. multicaudata and T. griffithii.

Tectaria beterocarpa has short erect rhizome, fronds compound, oblong-lanceolate, pinnae 5-15 per frond, terminal pinnae broader than lateral pinnae, apex long acuminate, sparsely pubescent, veins anastomosing with included veinlets, sori scattered, indusiate, spores monolete and margin spinulose (Figs. 2G-H, 3A-C). The Tectaria heterocarpa (Figure 3, A-C) is misidentified as T.pandurifolia (C. Chr. g) C. Chr., (1934:183) by Singh \& Panigrahi (Ferns Fern-Allies Arunachal Pradesh 2: 651652 , t. 242. 2005). At the younger stage T. heterocarpa produce a single, broadly ovate, stalked, terminal pinnae (sometimes fertile) which looks like a T. pandurifolia (Fraser-Jenkins et al. 2018). T. beterocarpa was also misreported as T. wightii because both the species doesn't produce basal bifurcate pinnae. However, T. wightii is differs from T. beterocarpa in having long creeping rhizome, lamina ovate-lanceolate pinnae are of same sized, sori in two rows (sometime scattered), exindusiate, spores monolete and margin spinulose (Patil et al. 2019a). T. impress is characterised by suberecterect rhizome, fronds dimorphic, fertile fronds longer and narrower than sterile one, lamina bipinnatifid-tripinnatifid, pubescent, veins anastomosing, forming copious subhexagonal areoles with simple included veinlets, sori indusiate, in row on both side of veins (Figure 3D-F). T. ingens is characterised by erect-suberect rhizome, fronds dimorphic, lamina tripinnate- quadripinnatifid, veins free, once or twice forked, reaching up to the margins, sori indusiate, present on tip of veins on both side of costule (Figure 3G-H). T. pseudosiifolia appears more or less similar to T. polymorpha. As shown in Figure 1A-B, it differs in having the dense white hairs on the stipe, rachis, pinnae and lobes. The lamina is bright green coloured, larger indusiate sori, subdimorphic, slightly smaller fertile frond, with dark stipes as compared to T. polymorpha.

In general, T. polymorpha is characterised by suberect or short creeping rhizome, bifurcation of only lower pinnae and sparsely hairy (Singh \& Panigrahi 2005; Fraser-Jenkins 2008; Kholia 2014 and Patil et al. 2019b). These characters of T. polymorpha can be verified even in the specimens growing in other part of the country including Western Ghats. However, considerable variations were observed in the morphology of individuals of this species growing in Meghalaya and Arunachal Pradesh, which showed long, stout, creeping rhizome, all pinnae bifurcated or sometimes lower pinnae shows quadrifurcate and less hair (Figure 4C-H).

Tectaria khonsaensis Sing \& Panigrahi, is described from Khonsa village, Arunachal Pradesh by Singh and Panigrahi (2005), which is similar to T. polymorpha but differs from later species by presence of hairs. Careful observation of line diagram and type photographs of T. khonsaensis provided by Singh and Panigrahi (2005) in Flora of Arunachal Pradesh showed absence of hairs. Authors of the present work tried to rectify the ambiguity by consulting the type specimen submitted to CNH but the type specimen could not be traced. Fraser-Jenkins (2008) when working on the check list on pteridophytes of Indian subcontinents, and "An annotated checklist of Indian Pteridophytes Part-2" Fraser-Jenkins et al. (2018), kept T. khonsaensis Sing \& Panigrahi under T. polymorpha.

Teactaria simonsii is characterised by creeping-suberect rhizome, fronds clustered; stipe dark brown or castaneous to black, pubescent throughout; lamina bipinnate to tripinnatifid, veins anastomosing, forming subhexagonal areoles with simple or forked included veinlets; sori exindusiate, orbicular arranged in irregular rows. T. subconfluens is characterised by suberect, stout rhizome with frond traces (Figure 4I-J), fronds clustered, dimorphic, stipe and rachis scaly, lamina bipinnate-bipinnatifid, decurrent, lower pinnae bipartite, fertile frond longer and narrower than sterile one, veins anastomosing with forked included veinlets, sori indusiate, scattered, situated on veinlets. 


\section{Acknowledgments}

Authors express their gratitude to the Director of the Botanical Survey of India for providing access to herbarium and local support. SMP is thankful to Science and Engineering Research Board (SERB) for financial support under NPDF programme. Authors would like to thank Mr. C. R. Fraser-Jenkins for confirmation of the species identity and constructive suggestion for the improvement of the text and also for providing the photograph of Tectaria chattagramica (Figure 1A).

\section{LITERATURE CITED}

Balasubramanian, A. 2017. Biodiversity Profile of India. Report submitted to Centre for Advanced Studies in Earth Science University of Mysore, Mysore. p. 11.

Banerjee (Mukherjee), R. \& Mukhopadhyay, R. 2008. Studies in the leaf epidermis and venation patterns of some Indian species of Tectarioid ferns. In: S.C. Verma, S.P. Khullar \& H.K. Cheema (eds.), Perspectives in Pteridophytes, Bishen Singh Mahendra Pal Singh, Dehra Dun. Pp. 397 - 405.

Barbhuiya, H. \& Singh S. 2014. Pteridophytes of Thorangtlang Wildlife Sanctuary, Mizoram, India. Journal of Threatened Taxa 6 (9): 6249 - 6268.

Beddome, R.H. 1883. Handbook to the Ferns of British India, Ceylon and the Malay Peninsula, Thacker Spink \& Co., Calcutta. p. 501.

Beddome, R.H. 1892. Supplement to the Ferns of British India, Ceylon and the Malay Peninsula, Thacker Spink \& Co., Calcutta. p. 110.

Benniamin, A.; Sundari, M. \& Tripathi, D. 2015. Addition to the fern flora of Nagaland. Korean Journal of Science 4: $15-18$.

Benniamin, A. 2010. Fern and fern-allies of Itanagar Wildlife Sanctuary. Indian Forester 33(2): $199-205$

Benniamin, A. 2012. The diversity of ferns and fern allies of Murlen National Park, Mizoram, North-East India. Indian Fern Journal 29: 1 - 12.

Bir, S.S.; Vasudeva, S.M. \& Kachroo, P. 1989. Pteridophytic flora of North-Eastern India I (Families: Huperziaceae-Sinopteridaceae). Indian Fern Journal 6: 30 - 55.

Bor, N.L. 1938. A sketch of vegetation of the Aka hills, Assam. A synecological study. Indian Forest Botany. Oxford Univ. Press. pp. 103 - 221.

Borthakur, S.K.; Deka, P. \& Nath, K.K. 2001. Illustrated manual of Fern of Assam. Bishen Singh Mahendra Pal Singh, Dehradun. p. 468.

Chandra, S. 2000. The Ferns of India: (Enumeration synonyms and distribution). International Book Distributors, Dehra Dun. p. 459.

Fraser-Jenkins, C.R.; Gandhi, K.N.; Kholia, B.S. \& Kandel DR. 2020. An Annotated Checklist of Indian Pteridophytes Part-3 (Lomariopsidaceae to Salviniaceae). Bishen Singh Mahendra Pal Singh, Dehra Dun. (Under Printing).

Fraser-Jenkins, C.R.; Gandhi, K.N. \& Kholia, B.S. 2018. An annotated checklist of Indian Pteridophytes Part-2 (Woodsiaceae to Dryopteridaceae). Bishen Singh Mahendra Pal Singh, Dehra Dun. p. 582.

Fraser-Jenkins. C.R. 2008. Three Hundred Indian Subcontinental Pteridophytes With a Revised Census List. Bishen Singh Mahendra Pal Singh, Dehra Dun. p. 685.

Gage, A.T. 1901. A botanical tour in the South Lushai Hills. Records of Botanical Survey of India 1: $331-369$. 
Gammie, G.A. 1895. Report on a botanical tour in the Lakhimpur district of Assam. Records of Botanical Survey of India 1 (5): $61-88$.

Ghosh, S.R.; Ghosh, B.; Biswas, A. \& Ghosh, R.K. 2004. The Pteridophytic Flora of Eastern India. Vol. 1. Botanical Survey of India, Kolkata. p. 591.

Handique, P.J. \& Konger, J. 1986. A list of fern and fern-allies of greater Guwahati, Assam (with their ecological adaptations). Mendel 3 (2): 130 - 135.

Hara, H. (ed.) 1966. Flora of Eastern Himalaya, $1^{\text {st }}$ Report. The University of Tokyo Press, Tokyo, Japan. p. 744.

Hara, H. (ed.) 1971. Flora of Eastern Himalaya, $2^{\text {nd }}$ Report. The University of Tokyo Press, Tokyo, Japan. p. 393.

Kachroo, P.; Bir, S.S. \& Vasudeva, S.M. 1989. Pteridophytic flora of North Eastern India- II (Families: Cryptogrammaceae-Thelypteridaceae). Indian Fern Journal 6: 78 - 99.

Kachroo, P. 1975. Fern flora of Assam with some Phytogeographical notes. Journal of Indian Botanical Society 54: 13 - 26.

Holttum, R.E. 1983. The fern genera Tectaria, Heterogonium and Ctenitis in the Mascarene Islands. Kew Bulletin 38: 107 - 130.

Mehra, P.N. \& Bir, S.S. 1964. Pteridophytic flora of Darjeeling and Sikkim Himalayas. Res. Bull. Punjab Univ. 15: 69 - 182.

Panigrahi, G. \& Choudhury, S. 1961. Taxonomic studies on the Aspidiaceae of Eastern India. Proceedings of the Indian Science Congress 48: 272.

Panigrahi, G. \& Choudhury S. 1962. Enumeration and distribution of Fern-allies in India. Proceedings of the Indian Science Congress 49: 25-256.

Panigrahi, G. \& Patnaik, S.N. 1961a. Pteridophytes of Eastern India-II: Polypodiaceaeenumeration of species with correct nomenclature. Indian Forester 87: 242 - 247.

Panigrahi, G. \& Patnaik SN. 1961b. Cytology of some genera of Polypodiaceae in Eastern India. Nature 191: 1207 - 1208.

Panigrahi, G. 1960. Pteridophytes of Eastern India: Enumeration of species collected and their nomenclature. Bulletin of the Botanical Survey of India 2: $309-314$.

Patil, S.M.; Benniamin, A. \& Rajput, K.S. 2020. Extended distribution for a rare fern Tectaria multicaudata in Peninsular India. Fern Gazette 21 (3): 121-124.

Patil, S.M.; Kachhiyapatel, R.N. \& Rajput, K.S. 2019a. Review on the genus Tectaria Cav., from India. Plant Science Today 6(2): $170-182$.

Patil, S.M.; Antony, R.; Nampy, S. \& Rajput, K.S. 2019b. Diversity, Distribution and Conservation Status of the Genus Tectaria Cav. from Deccan Peninsula and Western Ghats of India. Notulae Scientia Biologicae 11(3): 475 - 480.

Patil, S.M., Yadav, S.R. \& Dongare, M.M. 2014. Tectaria fuscipes (Tectariaceae, Pteridophyta), a New Record for Southern India. Journal of Japanese Botany 89: 186 - 188.

PPG-I. 2016. A community-derived classification for extant lycophytes and ferns. Journal of Systematics and Evolution 54 (6): 563 - 603.

Rawat, V.K. \& Sahu, R.T. 2009. Diversity, Distribution Pattern and Conservation of Pteridophytes in Mehao Wildlife Sanctuary, Arunachal Pradesh. Indian Forester 135(10): 1330 - 1346.

Salgado, A.E. 1982. Venation pattern in Pbillipine Tectarioid Ferns Monograph Series No 3 De la Salle University, Manila. 
Sharma, S.; Kumar, A.; Kholia, B.S. \& Bargali, S.S. 2018. New pteridophytic records from Mizoram, North-Eastern India. Journal of Threatened Taxa 10(6): 11822 - 11826.

Singh, B.; Singh, V.; Phukan, S.; Sinha, B. \& Borthakur, S. 2012. Contribution to the pteridophytic flora of India: Nokrek Biosphere Reserve, Meghalaya. Journal of Threatened Taxa 4(1)2: $277-294$.

Singh, S. \& Panigrahi, G. 2005. Fern and Fern allies of Arunachal Pradesh, Vols. 1 \& 2. Bishen Singh Mahendra Pal Singh. Dehra Dun. p. 881.

Singh, S.K.; Verma, D.; Kholia, B.S.; Sharma, S.; Sinha, B.K. \& Pandey, S. 2015. Pteridophytes of Tawi Wildlife Sanctuary, Mizoram, India. Korean Journal of Science 4: 19 - 30.

Sledge, W.A. 1972. The Tectarioid ferns of Ceylon. Kew Bulletin 27: 407 - 424.

Vasudeva, S.M.; Bir, S.S. \& Kachroo, P. 1990. Pteridophytic flora of North-Eastern India-III (Families: Aspleniaceae - Oleandraceae). Indian Fern Journal 7: 66 - 85. 